\title{
THE EFFECT OF ACTIVE LEARNING ON STUDENT CHARACTERISTICS IN A HUMAN PHYSIOLOGY COURSE FOR NONMAJORS
}

\author{
R. Russell Wilke \\ Biology Department, Angelo State University, ASU Station, San Angelo, Texas 76909
}

$\mathrm{T}$

his study investigated the effect of active-learning strategies on college students' achievement, motivation, and self-efficacy in a human physiology

course for nonmajors. Variables were studied via a quasi-experimental, Solomon four-group design on 141 students at a small west-Texas university. Treatment groups were taught using a continuum-based, active-learning model implemented over the course of a semester. Control groups were taught using traditional didactic lecture methods. To assess the effects of the continuum-based active learning strategies, students were administered a comprehensive physiology content exam, the Motivated Strategies for Learning Questionnaire, and attitude surveys. Factorial analyses indicated that the treatment groups acquired significantly more content knowledge and were significantly more self-efficacious than students in the control groups. There were no significant differences in motivation. Attitude surveys indicated that students in both the treatment and control groups demonstrated a positive attitude toward active learning, believed it helped (or would help) them to learn the material, and would choose an active learning course in the future.

ADV PHYSIOL EDUC 27: 207-223, 2003;

10.1152/advan.00003.2002

Key words: achievement; motivation; self-efficacy; college science teaching; Solomon

four-group design

The recent literature in higher education has commented that college science teaching needs improvement. Indeed, several "blue-ribbon agencies" have reported that the majority of US college science courses are taught using didactic means where student learning is passive $(11,30-32,46-47)$. It is no surprise, then, that students cite a lack of relevance, value, and meaning of science content, not to mention the often difficult, vague abstractions and unrelenting factual information as the main problems with college science teaching $(15,46,47,52,53)$. In addition, nonmajors cite that science is boring as well as difficult, contributing to a lack of confidence in their ability to do science $(44,47,54)$. Students, especially nonmajors, suffer from a lack of motivation to learn science, which further encourages poor attitudes toward science learning. Because of these challenges, these agencies strongly recommend more active instructional approaches to promote student learning and retention (11, 30-32, 46, 47). Active learning is viewed as a way of improving student learning in the science classroom by involving the student directly in the learning process. $(14,50)$.

Active learning is based on social cognitive theory and constructivism; however, there is a lack of continuity in the research literature on how "active learning" is defined $(9,10,14,28)$. This author uses the definition from Bonwell and Eison (9) that, "active learning involves students doing things and thinking about the

1043 - 4046/ 03 - \$5.00 - COPYRIGHT @ 2003 THE AMERICAN PHYSIOLOGICAL SOCIETY

VOLUME 27 : NUMBER 4 - ADVANCES IN PHYSIOLOGY EDUCATION - DECEMBER 2003 
things they are doing." In general, this includes 1) involving the students in the learning process, 2) placing less emphasis on transmitting knowledge and more on developing students' science process skills, 3) involving students in higher-order thinking skills, 4) engaging students in activities, and 5) placing a greater emphasis on students' own exploration of their attitudes, values, and beliefs about learning. As defined, active learning is predicted to produce meaningful learning, improve attitudes toward learning and science, increase knowledge and retention, and foster community among students, as well as motivate them to become self-regulated, independent learners $(7,14$, 16, 38). Active learning also promotes higher-level learning by 1) advancing the view that science is a process and not a set of facts to memorize, 2) promoting a belief in the student's own ability to learn about the subject (self-efficacy), 3) shifting the responsibility of learning away from the instructor and to the student, and 4) giving more value to the learning experience because the learner has done the work rather than being given the answer $(3,10$, 28, 50).

Despite the promise of active learning, college science teaching has been resistant to such changes in pedagogy, relying on more traditional didactic means of instruction $(1,11,23)$. In the literature, numerous reasons have been cited as barriers to pedagogical changes. For faculty, trying something new creates feelings of uneasiness and lack of confidence, not to mention the fact that faculty usually have few incentives to change their teaching styles $(9,26,33)$. Students and faculty also share similar expectations about one another's role in the classroom. Faculty are comfortable lecturing and view it as an effective means of transmitting information, whereas students come to expect faculty to be good lecturers $(18,27)$. Students are also resistant to change in the classroom, citing that they feel cheated or short-changed of content material if not lectured to (17). Faculty have also cited that, with active learning, they cannot cover as much content in the time available, that it takes increased course preparation time, or that they simply lack educational training. They also state that large classes prohibit active learning and that materials are lacking to support it (9).
This study investigates the use in the college science classroom of a continuum-based, active-learning model that addresses these barriers and investigates its effectiveness on learning outcomes. The primary objectives of the study were to determine whether an active-learning teaching strategy could improve students' achievement (ability to acquire content knowledge and application skills as defined by their performance on a comprehensive physiology content exam), motivation, and self-efficacy vs. that of a traditional lecture format.

\section{METHODS}

\section{Subjects}

The study was conducted at a small $(6,000$ students) west-Texas university on college students enrolled in a sophomore-level human physiology course. This four-credit-hour course enrolls primarily nonbiology majors who are required to take the course as part of their degree requirements in nursing, kinesiology, psychology, and medical technology. Although the class is largely composed of sophomores and juniors, the students come from diverse backgrounds; they are also required to complete a four-credit-hour anatomy course before enrolling in the course. Students are also concurrently enrolled in an accompanying laboratory course that meets one day a week for three hours. The lab instructional component of the course was not changed. Five lecture sections in human physiology students were solicited for the study. Three classes met twice a week for one hour and fifteen minutes and two classes met three times a week for $50 \mathrm{~min}$ for the duration of the 15-week semester.

\section{Experimental Design and Procedure}

Because students self-select into courses on the basis of personal choice, subjects could not be randomly assigned to treatment or control groups, nor could equal numbers of students be enrolled in each section. This limitation was addressed by using a "quasiexperimental" design, as outlined by Campbell and Stanley (12) and Cook and Campbell (13). Quasiexperimental designs assume that subjects cannot be randomly assigned to treatment or control groups, and thus groups may be unequal as far as students' gender, major, ability, background, etc. (the classes 
themselves were, however, randomly selected as treatment or control groups). The experimental design and analysis chosen, the Solomon four-group design (12), attempts to account statistically for any dissimilarities between treatment and control groups, but this is indeed a limitation of quasi-experimental designs.

The Solomon four-group design involves assignment of subjects to four groups. Two of the groups are pretested, and two groups are not. One of the pretested groups and one of the unpretested groups are subjected to the experimental treatment. The other two groups serve as controls. All four groups are then posttested (12) (Table 1).

The Solomon four-group design offers rigorous control of most sources of internal and external validity and allows for increased generalizability vs. other experimental designs, because the four design elements are paralleled $(12,13)$. The paralleled elements control for the possible effects of a pretest on students' subsequent performance and determines both the main effects and interactions of testing. If the pretest cues the students, both pretest groups will have higher posttest scores than the groups that do not receive the pretest. If there is an interaction between the pretest and the experimental treatment, so that the pretest provides an advantage to those students who receive only the treatment, the pretest-treatment-posttest group will have higher posttest scores than the treatment-posttest group $(1,12,13)$. Hence, this design allows for the investigation of variables as well as interaction effects.

Three instructors who were involved in the study had more than 20 years of combined college teaching experience with the course. In an attempt to control for teacher effect, two were each assigned a treat-

TABLE 1

Solomon four-group design

\begin{tabular}{ccc}
\hline Pretest & Treatment & Posttest \\
\hline $\mathrm{O}$ & $\mathrm{X}$ & $\mathrm{O}$ \\
$\mathrm{O}$ & $\mathrm{X}$ & $\mathrm{O}$ \\
& & $\mathrm{O}$ \\
& & $\mathrm{O}$ \\
\hline
\end{tabular}

$\mathrm{X}$, treatment; $\mathrm{O}$, dependent variables. ment group and a control group. The third instructor was assigned a treatment group only. To avoid potential biases from the exclusion of this section from the study, data were collected from a fifth class but were not used in subsequent analyses. To minimize the possible influence of variation in pedagogical styles among the three instructors, weekly meetings and daily e-mail correspondences were held to ensure constancy in content objectives (established a priori), depth of content coverage, and accurate implementation of the active-learning strategies. Course structure variables such as the text, content, grading, and exam formats were held constant and were based on content objectives.

Data were collected from the following instruments: ${ }^{1}$ a modified, comprehensive physiology content exam (19, 29), the Motivated Strategies Learning Questionnaire (MSLQ) (42), and an instructor-designed attitude survey. To determine the effectiveness of active learning on students' achievement, motivation, and selfefficacy, the posttest scores (means) of the comprehensive physiology content examination and the means of the scales and subscales of the MSLQ were statistically analyzed for differences between the groups using $2 \times 2$ factorial designs. ${ }^{2}$ Attitude survey data were analyzed using descriptive statistics and independent-samples $t$-tests. $\alpha$-Levels were set a priori at $P=0.05$. The instruments were all administered during the third week of class and one week before the students' final exam.

To control for the Hawthorne effect, all students were required to buy a student workbook, which served as a template for basic course content, lecture notes, and review problems. This student workbook mirrored the textbook and is available commercially (48). The study was limited to a 15 -week semester, as this represents the average course length offered at the

\footnotetext{
${ }^{1}$ These instruments were chosen for their previous published statistical reliablity/validity and because of their widespread use and availability. The instructor-designed survey had test/retest reliability $\alpha$-level of $P=0.76$.

${ }^{2}$ In $2 \times 2$ factorial designs, there are two treatment levels, the active-learning group and the lecture-only group, and two pretest levels, those that are pretested and those that are not. The factorial analysis discerns whether the active-learning treatment is effective by analyzing the posttest scores while also determining whether there is an interaction between the treatment (active-learning) and control (lecture-only) groups and the pretest.
} 
institution. The study considers students' achievement in the lecture, but not laboratory, portions of the course. This limitation is necessary because, although participating students are enrolled in corresponding laboratories, the laboratories were taught by a variety of instructors who were not participants in the study.

\section{Subject Profile}

A total of 200 students in human physiology were initially included when this study was initiated. However, due to an attrition rate that was not unexpected in this subject area, only 141 completed all requirements of the study. Because instruments were administered on different days (MWF vs. TTh) at the beginning and end of the study due to scheduling and because some students were absent on the days the instruments were given, the numbers of students who took the pretest and posttests varied between sections. These numbers were statistically accounted for by the analytical procedures used.

The number of students who completed the study in the treatment groups included 70 students. In this group, $62.90 \%$ were female, and $37.10 \%$ were male. By academic classification, seniors comprised the majority of students in this group, at $34.29 \%$ with sophomores second at $30.00 \%$. The remainder of the students were classified as juniors (22.86\%), freshman (7.14\%), and post-baccalaureate (5.71\%). The two most popular majors in the treatment group were kinesiology (32.86\%) and nursing (24.29\%). Majors classified as "other" were third $(15.70 \%)$. This category included majors such as elementary education, marketing, management, mathematics, early childhood, and chemistry and those students who were undeclared majors. Biology majors (14.29\%) and psychology majors (12.86\%) comprised the rest of the students.

A total of 71 students participated in the control groups. Like the treatment group, most of the students in this group were female (53.5\%), with fewer males (46.5\%), and the majority were classified as seniors at $40.85 \%$ (see Table 7.2). After the seniors, most students were juniors (29.57\%), followed by sophomores (22.54\%), freshmen $(5.63 \%)$, and postbaccalaureates (1.41\%). Kinesiology $(50.70 \%)$ and psychology (19.72\%) were the most popular majors in the control group, followed by nursing (15.49\%), biology (11.27\%), and those classified as "other" (2.82\%).

\section{Treatment and Control Groups}

Students enrolled in human physiology are instructed in material concerning normal cell physiology to overall normal operation of the body's tissue, organs, and organ systems. The primary objective of the course is to have students be able to describe and explain the normal function of the cells, tissues, organs, and organ systems of the human body (i.e., gain content knowledge and comprehension). The course content was the same for all classes participating in the study. Other course structure variables, such as the syllabus, text, content, grading procedures, and exam structure/formats, were held constant and did not deviate from previous course structure. The control groups were taught using the traditional, didactic lecture method of instruction (i.e., students listened as the instructor lectured on the content). The treatment groups were taught using a modified active-learning template/lesson plan that is based on an active-learning continuum $(10,20)$ (Table 2).

This instructional model begins with an initial engagement activity designed to briefly introduce content in a way that captures and focuses students' attention. The engagement activity is aimed at promoting advance organization of what the students know about the topic to be presented and establishing expectations about what the lecture will cover. These activities are based on instructor- or student-generated materials (see APPENDIX for specific examples). After the introduction, the instructor lectures on content relevant to the initial engagement activity. The next activity gives the students a chance to focus on the material that the instructor has just presented. The

TABLE 2

Basic active-learning lecture (modified)

\begin{tabular}{ll}
\hline Engagement activity & 5 minutes \\
Lecture segment & $15-20$ minutes \\
Activity & $5-10$ minutes \\
Lecture segment & $15-20$ minutes \\
Activity & $5-10$ minutes \\
Closure/evaluation & 10 minutes \\
\hline
\end{tabular}


instructor then delivers the second segment of lecture, followed by another activity, which focuses on the second segment. These activities include the pause procedure, minute papers, classroom assessment techniques, think-pair-share activities, simplified inquiry techniques, and case studies. (see APPENDIX for more detailed explanations and examples of the activities used). The closure/evaluation segment brings summation and closure to the day's lecture. Activities may include a short content quiz, summarization exercises, an application quiz, etc. The activity may also point students toward what the homework will cover or what will be presented in the next lecture. The lengths of the segments are chosen on the basis of previous research that demonstrates students' attention drops as a lecture progresses $(9,24)$. By use of the instructional model above as the basic template for the design and implementation of the active learning strategies, the study incorporated Bonwell and Sutherland's (10) idea of active-learning continua to meet course objectives, enhance student learning, and promote active learning (Table 3). As the course proceeded, the students were moved along these continua from 1) simple tasks involving informal sharing of information to more complex tasks involving critical thinking, science process skills, and inquiry; 2) simple acquisition of content to application of content to solve inquiry type problems; 3) individual student learning to learning involving interactions between students in informal cooperative groups; and 4) from being inexperienced active learners to experienced active learners $(10,20)$.

This approach allowed the technique to be introduced gradually over time to promote student acceptance and familiarity with the procedures while main-

TABLE 3

Active-learning continua

\begin{tabular}{llc}
\hline Simple tasks & $\rightarrow$ & $\begin{array}{c}\text { Complex tasks (continuum } \\
\text { of active-learning } \\
\text { complexity) }\end{array}$ \\
Knowledge acquisition & $\rightarrow$ & $\begin{array}{c}\text { Acquisition of skills/attitudes } \\
\text { (continuum of objectives) }\end{array}$ \\
Limited interaction & $\rightarrow$ & $\begin{array}{c}\text { Extensive interaction } \\
\text { (continum of classroom }\end{array}$ \\
Inexperienced & & interaction) \\
& & Experienced (continum of \\
& & student experience)
\end{tabular}

taining their expectations for learning by lecturing at the prescribed intervals. It also allowed faculty who were unfamiliar with active learning to start with simple activities that required little planning and little loss of classroom control to gain practice and experience before progressing to more sophisticated strategies. The activities were pilot tested over the course of a year in different courses, including introductory astronomy, introductory biology, human anatomy, and human physiology, to determine which worked best at enhancing student motivation and interest. Activities were subsequently modified on the basis of student acceptance and interest and for ease of implementation. Sample activities included engagement activities, the pause procedure, minute papers, thinkpair-share activities, classroom assessment techniques, and inquiry-based models $(4,8,20,51)$. The content material for these activities came from sources such as journal and news articles, videos, physiology texts, applications guides, and student workbooks (see APPENDIX).

At the beginning of the semester, the researchers implemented "lower-risk" active-learning strategies (e.g., the pause procedure, minute papers, think-pairshare, and classroom assessment techniques). Lowerrisk refers to the fact that the activities were rigorously structured, requiring little involvement from the students and little planning and/or loss of control from the instructor. For example, the initial activities included short, structured activities with explicit instructions, involving the students as individual learners (e.g., no interaction between the students and instructor centered). This initial lower-risk approach required little commitment from the student as regards oral participation. In other words, it did not require them to voluntarily or involuntary provide verbal feedback to the instructor. Students simply provided anonymous, written feedback to the instructor, as prescribed by the individual activities. This technique was used primarily to monitor student comprehension and understanding and provide written feedback to the instructor, who then relayed the information back to the students $(4,8,10,25,26,33)$. Toward the end of the first half of the semester, students formed informal learning groups with students in their immediate vicinity of two to four students each to share in the activities mentioned above (20). Students now shared information and tasks with 
each other on a voluntary basis. Students were also encouraged by the instructor to meet with different students during these informal learning opportunities.

Toward the end of the semester, more complex "higher-risk" activities were introduced (e.g., thinkpair-share, simplified inquiry, and case studies). Higher-risk activities were those that were less structured, involved more interaction on behalf of the students, and required more planning by the instructor, who theoretically had less control in the classroom when these were used. Students worked in informal, cooperative learning groups of two to four each to solve problems, answer inquiry-type questions, analyze case studies, and discuss articles or common experiences among themselves and with the class as a whole. These activities were designed to promote the application of physiology content knowledge and make the content relevant to the students' own academic majors. As the activities became more complex, the duration of the lecture segments shortened, and the duration of the activities lengthened proportionally as needed in the basic active-learning lecture template.

The active-learning lecture was used once a week in the treatment classes, beginning with the second class day. This model and frequency were chosen because previous pilot studies indicated that students are resistant to active learning on a daily basis when active strategies are used almost exclusively over lecture but accept active-learning strategies when used less frequently in combination with more didactic means. Results of the pilot studies indicated that using active learning just four times during the semester for a total of one hour and twenty minutes' worth of instruction was enough to produce significant results in favor of active-learning strategies. The other class days were spent in the traditional format, allowing for a total of 15 days spent in active learning out of 30 total class days in the semester. The activities themselves did not contribute in any way to the students overall course grades but only served as a means of feedback for students.

\section{RESULTS}

Statistical analyses yielded significant findings in the comprehensive physiology content exam and the self- efficacy section of the MSLQ. The analyses presented no significant differences on the value component or the affective component of the MSLQ's motivation scale. Attitude survey results suggested that students liked active learning, believed it helped them to learn the material, and would choose another active-learning course in the future.

\section{Comprehensive Physiology Content Exam Performance}

The comprehensive physiology content exam included 87 multiple-choice questions designed to measure students' recall, comprehension, and application of human physiology content knowledge. This exam was analyzed statistically to determine whether the experimental intervention had affected students' academic achievement as measured by the exam. The means \pm SD for the students' performance on the comprehensive physiology content exam are shown in Table 4.

The $2 \times 2$ factorial analysis determined that the treatment groups performed significantly better on the comprehensive physiology content exam than the control groups $(F=5.07, P=0.026$; Table 5). No difference was found between those student who took the exam as a pretest and those who did not. This indicates that students who had taken the exam as a pretest had no significant advantage over those who had not $(F=0.01, P=0.943)$. There was also no significant group by pretest interaction $(F=0.37, P=$ $0.546)$.

\section{MSLQ Results}

The MSLQ is a context-dependent, 81-item self-report instrument designed to evaluate college students' mo-

TABLE 4

Cell Means \pm SD for the comprehensive physiology content exam

\begin{tabular}{lcc}
\hline Source of Variation & $n$ & $\begin{array}{c}\text { Posttest } \\
\text { Scores }\end{array}$ \\
\hline $\begin{array}{l}\text { Treatment } \\
\text { Pretested }\end{array}$ & 34 & $47.38 \pm 11.38$ \\
$\quad$ Not pretested & 36 & $48.41 \pm 10.77$ \\
Control & & \\
$\quad$ Pretested & 41 & $44.12 \pm 10.89$ \\
$\quad$ Not pretested & 30 & $42.80 \pm 13.08$ \\
\hline
\end{tabular}


TABLE 5

Comprehensive physiology content exam $2 \times 2$ factorial $(n=141)$

\begin{tabular}{|c|c|c|c|c|c|}
\hline Source of Variation & SS & df & MS & $F$ & $P$ \\
\hline \multicolumn{6}{|l|}{ Main effects } \\
\hline Within (error) & $18,039.97$ & 137 & 131.68 & & \\
\hline Treatment vs. control group & 667.26 & 1 & 667.26 & 5.07 & 0.026 \\
\hline Pretest & .67 & 1 & .67 & 0.01 & 0.943 \\
\hline Group by pretest & 48.31 & 1 & 48.31 & 0.37 & 0.546 \\
\hline Between (model) & 716.24 & 3 & 238.75 & 1.81 & 0.148 \\
\hline Total & $18,756.21$ & 140 & 133.97 & & \\
\hline
\end{tabular}

SS, sum of squares; df, degrees of freedom; MS, mean squares.

tivation and their use of different learning strategies. The instrument consists of a motivation scale comprising three components and six subscales and a learning strategies scale comprising two components and nine subscales. Factorial analyses were applied to determine whether the treatment had affected students' motivation and self-efficacy. Analyses were therefore directed at the motivation (value and affective components) and self-efficacy scales within the motivation section of the MSLQ as a measure of students' motivation and self-efficacy. The means \pm SD for the MSLQ scores are included in Table 6.

Value component results. The value component of the MSLQ motivation scale measures students' interest and goal orientation and the value of the course. Higher means indicate more interest, value, and positive goal orientation in the course and serves as a measure of students' motivation. The factorial analysis revealed no significant differences between the treatment and control groups with regard to students' scores on the value component of the motivation scale of the MSLQ $(F=1.22, P=0.237)$, even though the means were higher in the treatment groups (Table 7). No differences were noted between the pretested groups ( $F=0.00, P=0.973)$. Likewise, there was no significant pretest by treatment interaction $(F=1.14$, $P=0.311)$.

Affective component results. The affective component of the MSLQ motivation scale measures how much students worry about tests and how often they have distracting thoughts when they take an exam. Higher means indicate more anxiety in testing situations, thus measuring the affective component of motivation. The factorial analysis revealed no significant differences between the treatment and control groups with regard to students' scores on the affective component of the motivation scale of the MSLQ ( $F=0.17, P=0.677$; Table 8 ). No differences were noted between the pretested groups $(F=1.92, P=$ $0.169)$, and there was no significant pretest by treatment interaction $(F=1.14, P=0.311)$.

TABLE 6

MSLQ components

\begin{tabular}{llcrl}
\hline & & & \multicolumn{2}{c}{ MSLQ Motivation Component } \\
\cline { 4 - 5 } Source of Variation & $n$ & Value component & Affective component & Self-efficacy component \\
\hline Treatment & & & & $5.08 \pm 1.18$ \\
$\quad$ Pretested & 31 & $4.89 \pm 0.99$ & $4.53 \pm 1.51$ & $5.00 \pm 1.07$ \\
$\quad$ Not pretested & 29 & $5.08 \pm 1.08$ & $3.87 \pm 1.34$ & $4.66 \pm 1.11$ \\
Control & 35 & $4.84 \pm 0.78$ & $4.01 \pm 1.43$ & $4.49 \pm 1.17$ \\
$\quad$ Pretested & 21 & $4.64 \pm 1.42$ & & \\
$\quad$ Not pretested & & & & \\
\hline
\end{tabular}

Values are means $\pm \mathrm{SD}$. MSLQ, motivated strategies learning questionnaire. 
TABLE 7

$2 \times 2$ MSLQ factorial-motivation scale: value component $(n=116)$

\begin{tabular}{|c|c|c|c|c|c|}
\hline Source of Variation & SS & df & MS & $F$ & $P$ \\
\hline \multicolumn{6}{|l|}{ Main effects } \\
\hline Within (error) & 123.61 & 112 & 1.10 & & \\
\hline Treatment vs. control group & 1.34 & 1 & 1.34 & 1.22 & 0.273 \\
\hline Pretest & 0.00 & 1 & 0.00 & 0.00 & 0.973 \\
\hline Group by pretest & 1.14 & 1 & 1.14 & 1.00 & 0.311 \\
\hline Between (model) & 2.48 & 3 & 0.83 & 0.75 & 0.524 \\
\hline Total & 126.09 & 115 & 1.10 & & \\
\hline
\end{tabular}

Self-efficacy component results. The self-efficacy component of the MSLQ measures students' expectancy of success, their perceptions of self-confidence in understanding the course content, and their control over those beliefs. The higher the means the better students believe they will do in the course and be able to master the course material. The factorial analysis revealed a significant difference between the treatment groups and the control groups with regard to their self-efficacy on the self-efficacy section of the MSLQ ( $F=4.14, P=0.044$; Table 9$)$. No significant differences were found between those who were pretested and those who were not $(F=0.00, P=$ $0.569)$, and there was no significant pretest by treatment interaction $(F=0.03, P=0.869)$.

\section{Attitude Survey Results}

The results of the attitude surveys administered at the beginning and end of the semester are discussed in this section. These surveys were designed to explore student perceptions of their self-efficacy toward physiology and attitude toward instruction, physiology, and course components without establishing a priori hypotheses about the effects of the treatment or control on these variables. Results were therefore allowed to emerge from the study and are reported below.

Beginning of the semester. To explore student self-efficacy toward physiology and attitude toward instruction, physiology, and course components and to avoid the potential biases associated with unequal pretesting in the different groups before the experiment, a 25-item instrument was constructed and administered to all groups at the beginning of the semester. The results of this attitude survey are expressed as a percentage of the total number of students who responded to the survey and appear in Table 10. Most students reported that they enjoy activities performed in class, like group discussions and interacting with others, and learn more from doing than from listening.

End of the semester. At the end of the semester, an expanded 25-item instrument was administered to all

TABLE 8

$2 \times 2$ MSLQ factorial-motivation scale: affective component $(n=116)$

\begin{tabular}{|c|c|c|c|c|c|}
\hline Source of Variation & SS & df & MS & $F$ & $P$ \\
\hline \multicolumn{6}{|l|}{ Main effects } \\
\hline Within (error) & 231.34 & 112 & 2.07 & & \\
\hline Treatment vs. control group & 0.36 & 1 & 0.36 & 0.17 & 0.677 \\
\hline Pretest & 3.97 & 1 & 3.97 & 1.92 & 0.169 \\
\hline Group by pretest & 1.36 & 1 & 1.36 & 0.66 & 0.420 \\
\hline Between (model) & 5.68 & 3 & 1.89 & 0.92 & 0.436 \\
\hline Total & 237.33 & 115 & 2.06 & & \\
\hline
\end{tabular}


TABLE 9

$2 \times 2$ MSLQ factorial: self-efficacy component $(n=116)$

\begin{tabular}{|c|c|c|c|c|c|}
\hline Source of Variation & SS & df & MS & $F$ & $P$ \\
\hline \multicolumn{6}{|l|}{ Main effects } \\
\hline Within (error) & 151.12 & 112 & 1.35 & & \\
\hline Treatment vs. control group & 5.59 & 1 & 5.59 & 4.14 & 0.044 \\
\hline Pretest & 0.44 & 1 & 0.44 & 0.33 & 0.569 \\
\hline Group by pretest & 0.04 & 1 & 0.04 & 0.03 & 0.869 \\
\hline Between (model) & 6.06 & 3 & 2.02 & 1.50 & 0.219 \\
\hline Total & 157.18 & 115 & 1.37 & & \\
\hline
\end{tabular}

groups to assess the same components; however, the instrument was tailored to assess different components in the treatment vs. the control groups. In addition to the components listed above, students in the treatment groups were asked to provide their opinions about the activities they had experienced, and in the control groups students were asked ques- tions about whether they would have liked the opportunity to participate in active learning. The results of the attitude survey for both the treatment and control groups are expressed as a percentage of the total number of students who responded to the survey (Tables 11 and 12). Because the surveys were different and the constructs were composed of differ-

TABLE 10

Beginning-of-semester attitude survey: all groups

\begin{tabular}{|c|c|c|c|c|c|c|}
\hline Item & Scale: $1=$ Strongly Disagree $\ldots 5=$ Strongly Agree & 1 & 2 & 3 & 4 & 5 \\
\hline 1 & $\begin{array}{l}\text { Answering the questions at the end of each textbook chapter will help me do } \\
\text { well in this class }\end{array}$ & 5.2 & 1.7 & 12 & 33 & 48 \\
\hline 2 & I like participating in group discussions in class & 7.6 & 8.1 & 41 & 25 & 19 \\
\hline 3 & Reading the textbook will help me understand the material in class & 2.3 & 6.9 & 15 & 39 & 37 \\
\hline 4 & I enjoy activities performed in class & 2.3 & 4 & 21 & 38 & 35 \\
\hline 5 & Reading the textbook will help me understand the material in this class & 2.3 & 3.5 & 16 & 38 & 41 \\
\hline 6 & I feel confident I can do well in human physiology & 5.2 & 9.2 & 31 & 35 & 20 \\
\hline 7 & I feel at ease in human physiology & 12 & 21 & 35 & 24 & 7.5 \\
\hline 8 & I learn more from doing than from listening & 3.5 & 7.5 & 23 & 29 & 37 \\
\hline 9 & Most people can understand human physiology & 13 & 27 & 41 & 15 & 3.5 \\
\hline 10 & $\begin{array}{l}\text { Performing the exercises in the student workbook will help me learn the material } \\
\text { for this class }\end{array}$ & 2.3 & 3.5 & 15 & 43 & 36 \\
\hline 11 & The subject of human physiology is interesting to me & 6.9 & 5.2 & 29 & 36 & 23 \\
\hline 12 & Doing the student workbook exercises will help me do well in this class & 2.3 & 2.3 & 16 & 43 & 36 \\
\hline 13 & I prefer classes where lecture is the only means of instruction & 22 & 31 & 26 & 13 & 8.1 \\
\hline 14 & I enjoy talking to other people about human physiology & 6.9 & 21 & 43 & 22 & 6.9 \\
\hline 15 & I really like human physiology & 8.7 & 19 & 35 & 27 & 10 \\
\hline 16 & Human physiology is too hard for me & 17 & 32 & 32 & 12 & 6.9 \\
\hline 17 & The experiments we perform in lab will help me reinforce what I learn in lecture & 2.9 & 6.4 & 25 & 42 & 24 \\
\hline 18 & I enjoy learning about human physiology & 5.8 & 8.7 & 34 & 41 & 12 \\
\hline 19 & Human physiology makes me feel uncomfortable & 15 & 32 & 30 & 16 & 8.1 \\
\hline 20 & I do not like to answer questions out-loud in class & 9.2 & 13 & 36 & 25 & 17 \\
\hline 21 & It makes me nervous to even think about doing a physiology experiment & 24 & 36 & 22 & 12 & 5.8 \\
\hline 22 & I like interacting with others in class & 2.9 & 9.8 & 30 & 35 & 22 \\
\hline 23 & I learn more from lecture than from activities & 15 & 23 & 43 & 14 & 5.8 \\
\hline 24 & It scares me to have to take a human physiology course & 12 & 31 & 32 & 15 & 11 \\
\hline 25 & I learn best when I am an active participant in class & 2.9 & 10 & 30 & 34 & 23 \\
\hline
\end{tabular}

Results are expressed as a percentage of the total number of students who replied to the survey ( $n=173)$. 
TABLE 11

End-of-semester attitude survey: treatment groups

\begin{tabular}{|c|c|c|c|c|c|c|}
\hline Item & Scale: $1=$ Strongly Disagree $\ldots .5=$ Strongly Agree & 1 & 2 & 3 & 4 & 5 \\
\hline 1 & The activities used in lecture were fun. & 5.8 & 8.7 & 21.7 & 39.1 & 24.6 \\
\hline 2 & Participating in the activities in class made me feel uncomfortable. & 29.4 & 32.4 & 23.5 & 8.8 & 5.9 \\
\hline 3 & I understood the point of the activities we did in class. & 1.4 & 12.9 & 10 & 41.4 & 34.3 \\
\hline 4 & Sometimes, I found myself thinking about the lecture activities when I studied. & 8.6 & 17.1 & 24.3 & 28.6 & 21.4 \\
\hline 5 & I attended this class more regularly than other classes I took this semester. & 10 & 12.9 & 20 & 14.3 & 42.9 \\
\hline 6 & The activities were too elementary for a college level class. & 48.6 & 32.9 & 8.6 & 2.9 & 7.1 \\
\hline 7 & $\begin{array}{l}\text { I found the inclusion of active learning in this course helped me understand the } \\
\text { material better. }\end{array}$ & 1.4 & 4.3 & 28.6 & 31.4 & 34.3 \\
\hline 8 & I liked the opportunity to work open-ended problems in class. & 2.9 & 4.3 & 22.9 & 42.9 & 27.1 \\
\hline 9 & $\begin{array}{l}\text { I would choose an active-learning course over a straight lecture course in the } \\
\text { future. }\end{array}$ & 4.3 & 8.6 & 12.9 & 32.9 & 41.4 \\
\hline 10 & $\begin{array}{l}\text { I believe I can use the problem solving skills I learned in class in other } \\
\text { situations. }\end{array}$ & 2.9 & 7.1 & 28.6 & 38.6 & 22.9 \\
\hline 11 & I felt comfortable answering questions out-loud in class. & 11.4 & 24.3 & 22.9 & 21.4 & 20 \\
\hline 12 & Active learning would be a good addition to other classes I'm taking. & 2.9 & 7.1 & 22.9 & 35.7 & 31.4 \\
\hline 13 & I felt comfortable contributing information out-loud in lecture. & 7.1 & 22.9 & 28.6 & 18.6 & 22.9 \\
\hline 14 & Lecture would have been boring without the activities. & 4.3 & 18.6 & 27.1 & 25.7 & 24.3 \\
\hline 15 & I learned a lot about human physiology in lecture. & 1.4 & 2.9 & 17.1 & 42.9 & 35.7 \\
\hline 16 & Human physiology is relevant to my own field of study. & 5.7 & 8.6 & 11.4 & 30 & 44.3 \\
\hline 17 & I liked the way lecture was taught. & 1.4 & 7.1 & 22.9 & 34.3 & 34.3 \\
\hline 18 & The student workbook helped me learn the material for this class. & 5.7 & 8.6 & 18.6 & 31.4 & 35.7 \\
\hline 19 & I prefer classes where lecture is the primary means of instruction. & 18.6 & 17.1 & 34.3 & 21.4 & 8.6 \\
\hline 20 & Human physiology is too hard for me. & 38.6 & 22.9 & 22.9 & 5.7 & 10 \\
\hline 21 & I enjoyed talking to other people in lecture about human physiology. & 2.9 & 14.3 & 40 & 31.4 & 11.4 \\
\hline 22 & I prefer classes that challenge me to think about the content. & 1.4 & 12.9 & 32.9 & 30 & 22.9 \\
\hline 23 & $\begin{array}{l}\text { Answering the end of chapter questions in the textbook helped me learn the } \\
\text { material for this class. }\end{array}$ & 1.4 & 7.2 & 17.4 & 49.3 & 24.6 \\
\hline 24 & I learn more from listening than from doing. & 14.3 & 24.3 & 42.9 & 12.9 & 4.3 \\
\hline 25 & I believe it is my own responsibility to learn the material presented in this class. & 2.9 & 8.6 & 24.3 & 14.3 & 48.6 \\
\hline
\end{tabular}

Results are expressed as a percentage of the total number of students who replied to the survey $(n=70)$.

ent items, no pairwise comparisons of the constructs could be made. Pairwise comparisons were made, however, for those items that were exactly the same (Table 13).

Treatment group. Students in the treatment group generally liked active learning, believed that activelearning strategies helped them understand the material better, and would choose an active-learning course over a straight lecture course in the future. Furthermore, students reported that human physiology was generally not too hard and that the course components helped them to learn physiology (Table 11).

Control Group. Students in the control groups indicated that in general active learning would be a good addition to human physiology . They also indicated that lectures were boring and that they would not choose a straight lecture course over an active learning course if given the opportunity in the future. Most students also reported that human physiology was too difficult for them, but that the course components did help them to learn and understand the material (Table 12).

Treatment vs. control groups. Pairwise comparisons using independent samples $t$-tests were used to test for significant differences between the treatment and control groups on those attitude survey items that were identical. The items are numbered for convenience and do not reflect their rank from the surveys which were randomly ordered (Table 13). Significant 
TABLE 12

End-of-semester attitude survey: control groups

\begin{tabular}{|c|c|c|c|c|c|c|}
\hline Item & Scale: $1=$ Strongly Disagree $\ldots 5=$ Strongly Agree & 1 & 2 & 3 & 4 & 5 \\
\hline 1 & I would have enjoyed the opportunity to work in groups. & 4.3 & 8.7 & 31.9 & 27.5 & 27.5 \\
\hline 2 & Active learning would have been a good addition to lecture. & 2.9 & 4.3 & 31.9 & 39.1 & 21.7 \\
\hline 3 & $\begin{array}{l}\text { I would choose a straight lecture course over an active learning course in } \\
\text { the future. }\end{array}$ & 30.4 & 33.3 & 21.7 & 5.8 & 8.7 \\
\hline 4 & Reading the textbook helped me understand the material. & 8.7 & 15.9 & 24.6 & 33.3 & 17.4 \\
\hline 5 & The lectures presented in class were boring. & 18.8 & 37.7 & 26.1 & 13 & 4.3 \\
\hline 6 & I attended this class more regularly than other classes I took this semester. & 4.4 & 10.3 & 22.1 & 25 & 38.2 \\
\hline 7 & The student workbook helped me learn the material for this class. & 4.3 & 11.6 & 29 & 15.9 & 39.1 \\
\hline 8 & $\begin{array}{l}\text { I believe I can use the problem solving skills I learned in class in other } \\
\text { situations. }\end{array}$ & 7.2 & 14.5 & 36.2 & 30.4 & 11.6 \\
\hline 9 & $\begin{array}{l}\text { Lecture would be more interesting if students could interact with one } \\
\text { another. }\end{array}$ & 4.3 & 14.5 & 39.1 & 21.7 & 20.3 \\
\hline 10 & I felt comfortable answering questions out-loud in class. & 21.7 & 23.2 & 33.3 & 17.4 & 4.3 \\
\hline 11 & The content of this class was boring for me. & 21.7 & 34.8 & 24.6 & 14.5 & 4.3 \\
\hline 12 & I liked the way lecture was taught. & 2.9 & 5.8 & 36.2 & 36.2 & 18.8 \\
\hline 13 & I prefer classes that challenge me to think. & 4.3 & 15.9 & 34.8 & 33.3 & 11.6 \\
\hline 14 & Human physiology is relevant to my own field of study. & 8.7 & 17.4 & 14.5 & 20.3 & 39.1 \\
\hline 15 & I learned a lot about human physiology in lecture. & 2.9 & 5.8 & 24.6 & 33.3 & 31.9 \\
\hline 16 & I learn more from listening than from doing. & 20.3 & 18.8 & 42 & 14.5 & 4.3 \\
\hline 17 & I prefer classes where lecture is the primary means of instruction. & 8.7 & 30.4 & 36.2 & 14.5 & 10.1 \\
\hline 18 & The lecture exams covered material I was expected to learn. & 2.9 & 5.8 & 23.2 & 37.7 & 30.4 \\
\hline 19 & I felt comfortable volunteering information out-loud in class. & 15.9 & 37.7 & 24.6 & 14.5 & 7.2 \\
\hline 20 & Human physiology is too hard for me. & 18.8 & 29 & 24.6 & 15.9 & 11.6 \\
\hline 21 & $\begin{array}{l}\text { I would have liked the opportunity to work on open-ended problems in } \\
\text { class. }\end{array}$ & 5.8 & 20.3 & 53.6 & 13 & 7.2 \\
\hline 22 & $\begin{array}{l}\text { Answering the end of chapter questions in the textbook helped me learn the } \\
\text { material for this class. }\end{array}$ & 2.9 & 10.1 & 24.6 & 36.2 & 26.1 \\
\hline 23 & I would have enjoyed discussing topics about human physiology with others. & 8.7 & 11.6 & 49.3 & 24.6 & 5.8 \\
\hline 24 & I learn more from doing than from listening. & 4.3 & 7.2 & 33.3 & 29 & 26.1 \\
\hline 25 & $\begin{array}{l}\text { I believe it is my own responsibility to learn the material presented in this } \\
\text { class. }\end{array}$ & 2.9 & 7.2 & 20.3 & 30.4 & 39.1 \\
\hline
\end{tabular}

Results are expressed as a percentage of the total number of students who replied to the survey ( $n=69$ ).

differences were found in items 2, 3, 4, and 10. This indicates that students in the treatment groups were much more comfortable interacting with each other and with the instructor than those students in the control groups for items 2, 3, and 4. Of interest is item 10, "Physiology is too hard for me," in which there was a significant difference between the treatment and control groups. More students in the treatment groups reported that they disagreed with the statement than did those students in the control groups $(t=-2.05 ; P=0.042)$. This statement concerns students' self-efficacy with regard to human physiology, which confirms earlier findings that selfefficacy differed significantly between the treatment and control groups.

\section{DISCUSSION}

\section{Achievement}

In the literature, the use of active-learning strategies has resulted in mixed effects on students' achievement. Some studies show that active learning can improve students achievement vs. traditional, didactic lecture (2, $14,20)$, whereas others show no difference at all (18, $21,22,43)$. In the present study, active-learning strategies used to teach the lecture portion of a human physiology course for nonmajors did result in improved achievement scores of students. Although this finding does not shatter previous conceptions about the effect of active learning on students' achievement scores, it does add to the knowledge base. 
TABLE 13

End-of-semester attitude survey: treatment vs. control

\begin{tabular}{|c|c|c|c|c|c|}
\hline Item & $\begin{array}{c}\text { Scale: } 1=\text { Strongly Disagree } \ldots \\
5=\text { Strongly Agree } \\
\text { Identical survey items }\end{array}$ & Treatment & Control & $t$-Value & $\begin{array}{l}\text { 2-Tail } \\
\text { significance }\end{array}$ \\
\hline 1 & $\begin{array}{l}\text { I attended this class more regularly than other } \\
\text { classes I took this semester }\end{array}$ & $3.68 \pm 1.14$ & $3.77 \pm 1.26$ & -0.38 & 0.703 \\
\hline 2 & $\begin{array}{l}\text { I believe I can use the problem-solving skills I } \\
\text { learned in class in other situations }\end{array}$ & $3.69 \pm 0.99$ & $3.24 \pm 1.08$ & 2.55 & 0.012 \\
\hline 3 & $\begin{array}{l}\text { I felt comfortable answering questions out-loud } \\
\text { in class }\end{array}$ & $3.17 \pm 1.29$ & $2.59 \pm 1.14$ & 2.79 & 0.006 \\
\hline 4 & $\begin{array}{l}\text { I felt comfortable volunteering information out- } \\
\text { loud in class }\end{array}$ & $3.25 \pm 1.24$ & $2.59 \pm 1.14$ & 3.21 & 0.002 \\
\hline 5 & $\begin{array}{l}\text { I learned a lot about human physiology in } \\
\text { lecture }\end{array}$ & $4.07 \pm 0.88$ & $3.83 \pm 1.08$ & 1.47 & 0.145 \\
\hline 6 & $\begin{array}{l}\text { Human physiology is relevant to my own field } \\
\text { of study }\end{array}$ & $3.97 \pm 1.2$ & $3.63 \pm 1.38$ & 1.51 & 0.133 \\
\hline 7 & I liked the way lecture was taught & $3.91 \pm 0.99$ & $3.62 \pm 0.96$ & 1.74 & 0.084 \\
\hline 8 & $\begin{array}{l}\text { The student workbook helped me learn the } \\
\text { material for class }\end{array}$ & $3.81 \pm 1.18$ & $3.74 \pm 1.22$ & 0.35 & 0.723 \\
\hline 9 & $\begin{array}{l}\text { I prefer classes where lecture is the primary } \\
\text { means of instruction }\end{array}$ & $2.84 \pm 1.22$ & $2.87 \pm 1.09$ & -0.15 & 0.884 \\
\hline 10 & Human physiology is too hard for me & $2.28 \pm 1.31$ & $2.72 \pm 1.27$ & -2.05 & 0.042 \\
\hline 11 & $\begin{array}{l}\text { I prefer classes that challenge me to think about } \\
\text { the content }\end{array}$ & $3.58 \pm 1.02$ & $3.32 \pm 1.02$ & 1.50 & 0.136 \\
\hline 12 & $\begin{array}{l}\text { Answering the end of chapter questions in the } \\
\text { textbook helped me learn the material for this } \\
\text { class }\end{array}$ & $3.81 \pm 1.02$ & $3.72 \pm 1.06$ & 0.49 & 0.623 \\
\hline 13 & I learn more from listening than from doing & $2.68 \pm 1.02$ & $2.64 \pm 1.10$ & 0.24 & 0.810 \\
\hline 14 & $\begin{array}{l}\text { I believe it is my own responsibility to learn the } \\
\text { material presented in class }\end{array}$ & $3.93 \pm 1.22$ & $3.96 \pm 1.08$ & -0.15 & 0.882 \\
\hline
\end{tabular}

Treatment and control values are means $\pm \mathrm{SD} ; n=69$.

An explanation for this finding should be sought in the theoretical basis for active learning and the justification for the use of a variety of strategies over the course of the semester. Because active-learning strategies are encompassed within the realm of constructivist thinking, it is easy to predict why these continuum-based, active-learning strategies produced these results. Constructivist teaching engages students in activities, encourages them to think and reflect on their learning experience, considers their prior knowledge, and provides feedback during the learning process $(36,55)$. Studies show that a constructivist approach to teaching produces positive outcomes of learning, including achievement (55). The activelearning strategies used in this study incorporated these tenets by providing students with the opportunity to engage in listening, reading, writing, discussing, reflecting, and problem solving in the classroom. By use of an active approach to teaching and learning, the results on students' achievement were positive. Students in the lecture-only classes did not have these opportunities.

Active learning strategies in this study did lead to an improvement in students' content achievement. The implications of this finding are that active learning can produce the desired achievement results even when content coverage is reduced. Other researchers have reported that, when content coverage was decreased in a nonmajors' college biology course, students' achievement scores and attitudes toward science were statistically better than those of biology majors whose achievement on the same content and attitudes toward science were lower (49). This study adds to the mounting evidence that "less is more," and should come as encouragement to instructors in content-intensive disciplines who are hesitant to incorporate active learning in their classrooms. Content 
coverage is often the bane of college science teaching where the thought is that students will not learn the content if it is not addressed by way of lecture. To hold onto this thought may actually deprive students of actual content knowledge. With minimal preparation and "risk" to the students and to the instructors themselves, active learning in the context of this study can produce the desired achievement results.

\section{Motivation}

The use of active-learning strategies in a human physiology course did not result in an increase in students' motivation. The theoretical basis for active learning and studies from the literature report that active learning can increase student motivation by generating student interest, which translates into meaningful learning and task value $(14,21,28,37,55)$. In seeking an explanation for these results, it may be relevant to consider the theoretical basis for motivation, the method in which it was measured, the nature of the material being learned, and the learners themselves.

Motivation was defined by this study from a general social-cognitive model of motivation that incorporates three motivational constructs: value, expectancy, and affect $(37,38)$. The value and affective components were measured by the MSLQ to ascertain whether changes in these constructs occurred as a result of instruction. The value component of the MSLQ motivation scale measures students' judgments of how interesting, useful, and important the course content is along with a measure of how they focus on learning (mastery vs. performance orientation) (40). Nonscience majors often claim that science courses are uninteresting and lacking in meaning and relevance, so the active-learning strategies were designed to help facilitate student interest $(44,52)$. However, activities designed to enhance student interest (simplified inquiry and case studies) were implemented at end of semester (end of the continuum), when limited time and exposure may have contributed to students' lack of interest and perception of relevance and therefore perception of value in the course.

This was further exacerbated by the number of different majors the course serves, because with the limited exposure to these activities came limited time to make meaningful connections to each of the dif- ferent content areas. On the whole, students may have failed to see the connection or relevance of the course to their own particular academic major. Because the strategies designed to connect the content to students' own majors were not introduced until the very end of the semester via simple inquiry and case studies, their duration may not have been enough to effect a change in the students' perception of value toward the course and thus their motivation. Because interest, meaning, and relevance are measures of intrinsic motivation (40), the activities used in this manner may thus have failed to generate the requisite interest and perception of value required to promote motivational change.

For the affective component of the motivation scale of the MSLQ, no significant change was detected between the two groups. To explain these results, it may be relevant to consider the behavior of the students enrolled in the course and the links between motivation and achievement. The activities, although resulting in greater achievement gains in students, may not have been able to address students' worry and concern over taking exams. Human physiology has a reputation for being a difficult course, not only at the university used in this study but at other universities as well (22). The majority of the students who enroll in this sophomore-level course are upperclassmen who delay taking human physiology until the last possible moment, many waiting until the semester they plan to graduate in. This behavior suggests that students may have an aversion to taking human physiology and as a result may worry excessively over taking exams. This fear and aversion to science courses has been reported in the literature (52-54). In fact, Baldwin et al. (5) report that, if a college student thinks he/she does not have the ability to do well in science, then that lack of confidence in his/her ability may lead to a poor attitude toward science. This may, in turn, lead to an avoidance of science courses.

Moreover, new research also suggests that students' epistemology, their beliefs about the nature and knowledge of learning, is related to their motivation and that these epistemologies may vary by students' academic major. This may explain why no difference in the affective portion of students' motivation was found. Paulsen and Feldman (35) determined that 
students who have naive beliefs about learning and knowledge were more likely to be less motivated and have higher levels of test anxiety ${ }^{3}$ than were students with more sophisticated beliefs. Students in human physiology often have little science background and come from a variety of majors. They may have viewed the content from a less sophisticated view due to their lack of science background; however, more work needs to be done in this area. Furthermore, even though active-learning strategies did not significantly benefit students' motivation, their use did enhance their achievement and self-efficacy. These findings imply that activities should be directed more at making the content more relevant and meaningful in the future, possibly with more duration and frequency.

\section{Self-Efficacy}

Active-learning strategies used in this study resulted in an improvement of students' self-efficacy, but what exactly is self-efficacy and how does it relate to active learning? Self-efficacy is characterized by one's beliefs about behavioral outcomes, coupled with expectations about one's ability to engage in, execute, persist in, and be successful at a particular behavior (6), in this case science. Because many nonscience majors come to our courses with negative attitudes and low self-efficacy, it is imperative to nurture feelings of confidence from the very beginning. The use of active-learning strategies alone is reported to significantly increase or change students' science self-efficacy by promoting a belief in their own ability to do science and be successful in learning about it $(3,17$, 50 ). The strategies in this study were indeed designed to help students gain confidence in and have control over their abilities to learn human physiology and be successful in doing so, but the strategies were also introduced gradually over the course of the semester on the basis of an active-learning continuum. This was to enable students to see the results of their efforts and receive feedback in a relatively risk-free environment and thus help them develop their self-efficacy over the course of the entire semester. Because students were active participants in the learning process,

${ }^{3}$ Although not explicitly addressed by the intervention, test anxiety is known to be inversely related to academic performance as well as motivation $(37,56)$. self-efficacy was improved compared with those students who experienced traditional didactic lectures.

What these findings suggest is that self-efficacy and classroom success are linked and that an individual's level of engagement in a task and willingness to persist at the task are indicators of success $(35,41)$; however, the literature reveals that self-efficacy is also inextricably linked to achievement $(34,37,38)$. Thus it is logical to conclude that, if students' confidence in their abilities to do science increases, so will their achievement, and in this case it does. For teachers of nonmajors in fact-filled courses where grades are often dismal and achievement low, this should also come as encouragement and a justification for using active learning in the college science classroom.

\section{IMPLICATIONS FOR PRACTICE}

The continuum-based, active-learning strategies in this study significantly improved students' achievement in physiology content knowledge and their selfefficacy with regard to science. The strategies 1) considered student and faculty expectations about teaching and learning, 2) addressed barriers to active learning, and 3) required minimal planning, time, and resources. Despite these positive findings, the strategies had no effect on student motivation, but students did report they liked active learning and valued it as a means of instruction. The long-term effects of these improvements, however, remain to be investigated. The results imply at best that college science instructors should consider using active-learning strategies in their classrooms, since improvement in student achievement and self-efficacy were found compared with that of traditional didactic instruction.

That said, the results discussed here do not provide conclusive evidence for the wholesale use of active learning in postsecondary science education, but they do contribute to the growing body of knowledge in support of these strategies. As always, replication studies are needed, especially in the social sciences, where progress occurs through the application of many experiments. Unlike the natural sciences, where a cleverly designed experiment can settle a long-standing theoretical controversy, experiments in science education and the whole of the social sciences are dependent on contributions to an entire 
body of research. Each individual experiment contributes only a piece or pieces to the educational puzzles that challenge us, and although no one study can totally put it all together, progress is still made. Although the teaching of nonscience majors will always remain a challenge, this study has demonstrated that active-learning strategies used on a continuum produce desirable outcomes of instruction, even in the face of the barriers cited by students and faculty. For practitioners in higher science education who take pride in their continual quest for pieces of that puzzle, this study puts them one piece closer to eventual understanding.

\section{APPENDIX}

\section{Active Learning Strategies}

Engagement activities. These activities serve to organize in advance what the topic of the lecture will be. The activities serve to access students prior knowledge, identify misconceptions, and get students thinking about the topic for the day. These engagement activities include, but are not limited to, playing a song, reciting a humorous anecdote, displaying relevant cartoons, showing a demonstration, reading pieces of news or journal articles from the various fields of the students, stating a problem, a controversial solution to a problem or a paradox suggested by the content, and questions or problems generated by the students. The instructor then ties in the engagement activity to the day's topic via lecture or class discussion.

Pause procedure. Based on research on human attention spans, this strategy requires the instructor to stop lecturing every 13-18 minutes to allow the students to do something else for a short period of time ranging from one to five minutes. For example, the instructor can ask the students to reflect on or review their notes and then ask for questions. Students can also compare notes with each other to determine whether they should add anything to their own notes on the basis of their review of their neighbors'. This strategy is often used in conjunction with the minute papers listed below.

Minute papers. This strategy has the lecture punctuated with periodic short writing assignments that the students do on their own or with a partner and that typically take "only a minute" to do. The instructor can pose questions, such as what was the most important thing you learned in class, what was confusing about today's lecture, what would you like to know more about, what was the main idea presented today, what are some of the major concepts associated with today's topic, to get students to reflect on and think about what they have learned. The students can write their answers anonymously and work independently, in pairs, or in groups. The instructor collects the minute papers for feedback, or they can serve as the basis for a class discussion. Variations include the main-points paper, which asks students to write what they think are the main points of the lecture, the muddiest-points paper, which asks students to write what they are having trouble comprehending, and running paper, which asks students the same question at different points in the lecture (beginning, middle, and end). All, however, give students a chance to reflect on what they are learning and give those who may be reluctant to ask question in class a chance to get feedback from the instructor without fear of embarrassment.

Think-pair-share activities. This procedure has two students discuss together for several minutes what they think an appropriate answer is to a question posed by the instructor or another student. The student pairs then write down their answer(s), and the instructor harvests responses from the class. The instructor then goes over the responses with the class as a whole. This procedure allows students to share in the responsibility of an answer and reduces the fear and intimidation students may have in a large class. This procedure can be modified to reflect varying degrees of student interaction and inquiry in the class. It has also been called a "feedback lecture," in which the instructor provides the students with content information before posing a problem or case study to the class as a whole. Students can work alone, in pairs, or in groups in an attempt to use the information they have just received to solve the problem. The students' responses are harvested by the instructor and shown to the entire class. A class discussion takes place, with the class and instructor identifying solutions that are not possible with justifications until the optimal answer is identified. The instructor can then give the students more information to further complicate the problem, followed by more student work, and so on throughout the class. The instructor and the students receive feedback about the learning that is occurring and at a time when something can be done quickly to correct misunderstandings.

Classroom assessment techniques, Angelo and Cross (4) have an excellent resource guide that employs many active-learning strategies to allow students and instructors to get feedback about learning in the classroom in conjunction with specific course objectives. This study employed many of the strategies contained in that reference. For more detailed descriptions please see their text.

Simplified-inquiry sequence. In this design, students are given an authentic and relatively concrete problem, which they can then solve on their own or in informal groups. They must decide:

- what they know to be the facts about the case, situation, or problem

- what they know that would be useful in solving the case

- what information they still need and how to get it

- what some possible solutions might be and how to differentiate among them.

They obtain additional information, reflect, reanalyze, and repeat the cycle until the problem is solved. The sequence can be modified as necessary to reflect varying degrees of structure or inquiry 
(M. D. Svinicki, Center for Teaching Effectiveness, The University of Texas at Austin, used by permission).

\section{Case Study}

This is a special type of inquiry method, which consists of a detailed study of a particular situation, scenario, decision, or issue that the students analyze and draw conclusions from. The case study can give students understanding of difficult, complex matters concerning the content.

- Select and define a topic or problem to investigate. This could be suggested by the instructor or by the students, concerning a topic of general interest.

- Identify, collect, and make ready the materials needed for study. This usually includes reading material such as textbooks, journal articles, etc. but could also include video and audio clips and/or pictures.

- Introduce the topic. Generally, the instructor does this, assisting as necessary by pointing out the specifics of the problem or issue, what the students are attempting to find out, and the method of attack. The students can work alone or in groups as they investigate the case.

- Share findings and conclusions. This can be done in many ways. Students can write a report, participate in role playing, or participate in class discussion. Callahan et al. (11a) have an excellent review of case study basics. Their sequence was used for the case study portion of this study.

I thank Drs. Marilla Svinicki and Dee U. Silverthorn, both of the Univ. of Texas at Austin, for their assistance in this study.

Submitted 15 January 2002; accepted in final form 17 September 2003

Address for reprint requests and other correspondence: $R$. R. Wilke, Biology Department, Angelo State University, ASU Station, San Angelo, TX 76909-0890.

\section{References}

1. Abraham MR and Cracolice MS. Doing research on college science instruction. J College Sci Teaching 23: 150-153, 1994.

2. Albanese MA and Mitchell S. Problem-based learning: a review of literature on its outcomes and implementation issues. Acad Med 68: 52-68, 1993

3. Allen DE, Duch BJ, and Groh SE. The power of problembased learning in teaching introductory science courses. New Directions Teaching Learning 68: 43-51, 1996.

4. Angelo T and Cross KP. Classroom Assessment Techniques. San Francisco: Jossey-Bass, 1993.

5. Baldwin JA, Ebert-May D, and Burns DJ. The development of a college biology self-efficacy instrument for non-majors. $S c i$ Educ 83: 397-408, 1999.
6. Bandura A. Self-efficacy: toward a unifying theory of behavioral change. Psychol Rev 84: 191-215, 1977.

7. Barrows HS. A taxonomy of problem-based learning methods Med Educ 20: 481-486, 1986.

8. Bonwell CC. Enhancing the lecture: revitalizing a traditional format. New Directions Teaching Learning 67: 31-44, 1996.

9. Bonwell CC and Eison JA. Active Learning: Creating Excitement in the Classroom ASHE-ERIC Higher Education Report No. 1. Washington DC: Geo. Washington Univ. School of Education and Human Development, 1991.

10. Bonwell CC and Sutherland TE. The active learning continuum: choosing activities to engage students in the classroom. New Directions Teaching Learning 67: 3-16, 1996.

11. Boyer Commission on Education Undergraduates in the Research University. Reinventing Undergraduate Education: A Blueprint for America's Research Universities. Washington, DC: Carnegie Foundation for the Advancement of Teaching, 1998.

11a.Callahan JF, Clark LH, and Kellough RD. Teaching in the Middle and Secondary Schools (5th ed.). Englewood Cliffs, NJ: Prentice-Hall, 1995.

12. Campbell DT and Stanley JC. Experimental and Quasiexperimental Designs for Research: A Handbook for Research on Interactions. Boston, MA: Houghton Mifflin, 1963.

13. Cook TD and Campbell DT. Quasi-Experimentation: Design and Analysis Issues for Field Settings. Chicago, IL: RandMcNally College Publishing, 1979.

14. Ebert-May D, Brewer C, and Allred S. Innovation in large lectures-teaching for active learning. Bioscience 47: 601$607,1997$.

15. Felder RM. Reaching the second tier: learning and teaching styles in college science education. J College Sci Teaching 23: 286-290, 1993

16. Hammer D. Discovery learning and discovery teaching. $\operatorname{Cog}$ nition and Instruction 22: 163-168, 1997.

17. Hemenway MK, Straits WJ, Wilke RR, and Hufnagel $B$. Educational Research in an Introductory Astronomy Course. Innov Higher Educ 26: 178-269, 2001.

18. Huang AH and Carroll RG. Incorporating active learning into a traditional curriculum. Am J Physiol Adv Physiol Educ 273: S14-S23, 1997.

19. Human Anatomy and Physiology Society. HAPS standardized examination progress report. HAPS-Educator November: p. 11-12, 1996.

20. Johnson DW, Johnson R, and Smith K. Active Learning: Cooperation in the College Classroom. Edina, MN: Interaction Book, 1998.

21. Lord T. A comparison between traditional and constructivist teaching in college biology. Innov Higher Educ 21: 197-216, 1997.

22. Lunsford BE and Herzog MJR. Active learning in anatomy and physiology. Am Biol Teacher 59: 81-84, 1997.

23. McIntosh WJ. The dynamics of change in college science teaching. J College Sci Teaching 26: 206-208, 1997.

24. McKeachie WJ, Pintrich PR, Yi-Guang L, and Smith DAF. Teaching and Learning in the College Classroom: A Review of the Research Literature. Ann Arbor, MI: Regents of the Univ. of Michigan, 1986 
25. Miller JE, Groccia JE, and Wilkes JM. Providing structure: the critical element. New Directions Teaching Learning 67: 17-30, 1996.

26. Modell HI. Preparing students to participate in an active learning environment. Am J Physiol Adv Physiol Educ 270: S69S77, 1996.

27. Modell HI and Michael JA. Promoting active learning in the life science classroom: defining the issues. Ann NY Acad Sci 701: 1-7, 1993.

28. Meyers C and Jones TB. Promoting Active Learning. San Francisco: Jossey Bass, 1993.

29. Munn PP. Test Item File, Human Physiology: An Integrated Approach. Upper Saddle River, NJ: Prentice Hall, 1998.

30. National Research Council. From Analysis to Action: Undergraduate Education in Science, Mathematics, Engineering, and Technology. Washington, DC: National Academy, 1996.

31. National Research Council. National Science Education Standards. Washington, DC: National Academy, 1996.

32. National Science Foundation. New Expectations for Undergraduate Education in Science, Mathematics, Engineering, and Technology. Washington, DC: NSF, 1996

33. Orzechowski RF. Factors to consider before introducing active learning into a large, lecture based course. J College Sci Teaching 24: 347-349, 1995.

34. Pajares F. Self-efficacy beliefs in academic settings. Rev Educ Res 66: 543-578, 1996.

35. Paulsen MB and Feldman KA. Student motivation and epistemological beliefs. New Directions Teaching Learning 78: 17-25, 1999

36. Piaget J. The Construction of Reality in the Child. New York: Base Books, 1964.

37. Pintrich PR. A process-oriented view of student motivation and cognition. In: Improving Teaching and Learning Through Research: New Directions for Institutional Research, edited by Stakr J and Mets L. San Francisco: Jossey Bass, 1988, vol. 57, p. 65-79.

38. Pintrich PR. The dynamic interplay of student motivation and cognition in the college classroom, In: Advances in Motivation and Achievement: Motivation-Enhancing Environments, edited by Ames C and Maehr ML. Greenwich, CT: JAI, 1989, vol. 6 , p. 117-160.

39. Pintrich PF and Garcia T. Student goal orientation and selfregulation in the college classroom. In: Advances in Motiva tion and Achievement: Goals and Self-Regulatory Process, edited by Maehr M and Pintrich PR. Greenwich CT: JAI, 1991, vol. 7 , p. 371- 402 .

40. Pintrich PR and Garcia T. Assessing students' motivation and learning strategies. Meeting Am Educ Res Assoc 1995 April,
San Francisco, CA. (ASHE-ERIC Document Reproduction Service No. ED 383 770)

41. Pintrich PR, Marx RW, and Boyle RA. Beyond cold conceptual change: the role of motivational beliefs and classroom contextual factors in the process of conceptual change. Rev Educ Res 63: 167-199, 1993.

42. Pintrich PR, Smith DA, Garcia T, and McKeachie WJ. Reliability and predictive validity of the motivated strategies for learning questionnaire (MSLQ). Educ Psychol Measurement 53: 801-813, 1993.

43. Richardson $\mathbf{D}$ and Birge B. Teaching physiology by combined passive (pedagogical) and active (androgogical) meth ods. Am J Physiol Adv Physiol Educ 268: S66-S74, 1995.

44. Rigden JS and Tobias S. Point of View. Too often, collegelevel science is dull as well as difficult. Chronicle Higher Educ: A52, 1991.

45. Ruhl KL, Hughes CA, and Schloss PJ. Using the pause procedure to enhance lecture recall. Teacher Educ Special Educ 10: 14-18, 1987.

46. Seymour E. Revisiting the problem iceberg. $J$ College Sci Teaching 24: 392-396, 1995.

47. Seymour E and Hewitt NM. Talking About Leaving: Why Undergraduates Leave the Sciences. Boulder, CO: Westview, 1996.

48. Silverthorn DU, Hill RD, and Brewer LD. Human Physiology: An Integrated Approach, Student Workbook, Upper Saddle River, NJ: Prentice Hall, 1998.

49. Sundberg MD, Dini ML, and Li E. Decreasing course content improves students comprehension of science and attitudes toward science in freshman biology. $J$ Res Sci Teaching 31: 679-639, 1994

50. Svinicki MD. A theoretical foundation for discovery learning. Am J Physiol Adv Physiol Educ 275: S4-S7, 1998.

51. Svinicki MD and Dixon NM. The Kolb model modified for classroom activities. College Teaching 35: 141-146, 1987.

52. Tobias S. They're Not Dumb, They're Different: Stalking the Second Tier. Tucson, AZ: Research Corp., 1990.

53. Tobias S. Revitalizing Undergraduate Science. Tucson, AZ: Research Corp., 1992.

54. Trafil J and Hazen R. The Sciences: An Integrated Approach. New York: Wiley and Sons, 1995.

55. Yager RE. The constructivist learning model: towards real reform in science education. Sci Teacher 58: 52-57, 1991

56. Zoller $U$ and Ben-Chaim D. Interaction between examination type, anxiety state, and academic achievement in college science; an action-oriented research. $J$ Res Sci Teaching 26 : 65-77, 1988. 